\title{
Peran Ketua Program Studi Dalam Membentuk Karakter Kepemimpinan Mahasiswa Melalui Kegiatan Himpunan Mahasiswa Program Studi (HMPS)
}

\author{
${ }^{1}$ Baiq Rohiyatun, ${ }^{2}$ Menik Aryani \\ Universitas Pendidikan Mandalika \\ Email:bq.rohiyatun@gmail.com
}

\begin{abstract}
Abstrak. Pendidikan di perguruan tinggi memiliki karakter yang berbeda dengan pendidikan dasar maupun menengah. Salah satu perbedaan itu adalah pada peran mahasiswa yang semakin besar dalam menentukan keberhasilan pendidikan mereka. Mahasiswa sebagai subjek pembelajaran di perguruan tinggi mestilah menjadi perhatian utama seluruh pelaksana pendidikan dalam rangka menjadikannya manusia yang memiliki kompetensi tinggi. Di sinilah tugas ketua Program studi dalam memberikan kesempatan kepada para mahasiswa dengan menyediakan sebanyak mungkin wadah untuk menempa diri selain di dalam ruang kuliah. Kegiatan ekstrakulrikuler juga mestinya mendapat perhatian yang banyak dari ketua Program studi agar dapat menjadi tempat belajar yang baik bagi para mahasiswa selain di ruang kelas. Ada banyak kegiatan ekstrakurikuler yang ditawarkan oleh sebuah perguruan tinggi yang dapat diikuti oleh setiap mahasiswa. Ekstrakurikuler di perguruan tinggi di antaranya adalah Unit Kegiatan Mahasiswa (UKM) dan Himpunan Mahasiswa. Metode penelitian yang digunakan adalah metodologi penelitian deskriptif dengan pendekatan deskriptif kualitatif. Subjek penelitian adalah seluruh Himpunan Mahasiswa Program Studi yang ada di UNDIKMA. Teknik pengumpulan data yang digunakan ada empat tahapan, yaitu: (1) teknik observasi, (2) teknik wawancara, (3) teknik dokumentasi, dan (4) teknik triangulasi (gabungan). Pembahsan dari hasil penelitian yaitu: ketua Program Studi melakukan komunikasi yang baik dalam setiap kegiatan. Komunikasi yang dilakukan antara ketua Program Studi maupun dengan Himpunan Mahasiswa disesuaikan dengan kebutuhan apa yang akan dikomunikasikan. ketua Program Studi masing-masing memiliki peran di dalamnya, porsi dari peran keduanya disesuaikan dengan tingkat kebutuhan pada saat dibutuhkan dan disesuaikan dengan situasi dan kondisi yang ada dan secara keseluruhan berperan sebagai pengarah sebagai ujung tombak pengawasan dan pembinaan di lapangan. Karakter Kepemimpinan yang Dibentuk melalui Kegiatan Himpunan Mahasiswa Program Studi antara lain: Cerdas, Disiplin, tanggung jawab, jujur dan benar, berani mengambil resiko, dan inovatif.
\end{abstract}

Kata kunci: Karakter, kepemimpinan, Himpunan, Mahasiswa 


\section{PENDAHULUAN}

Dalam sebuah program studi di perguruan tinggi, ketua Program studi memiliki peran yang besar dalam mensukseskan jalannya pendidikan di program studi tersebut. Ketua Program studi adalah penanggung jawab dan pemimpin tertinggi di lembaga Program studi. Sebagaimana disampaikan oleh Wahjosumidjo (2001, hlm. 82) dan Mulyasa (2013, hlm. 97) bahwa seorang pemimpin di lembaga pendidikan memegang kunci atas berhasil atau tidaknya lembaga tersebut. Pola kepemimpinan yang dilaksanakan akan sangat berpengaruh bahkan sangat menentukan kemajuan lembaga pendidikan yang dipimpinnya. Oleh karena itu, dalam pendidikan modern kepemimpinan pemimpin lembaga pendidikan merupakan jabatan strategis dalam mencapai tujuan pendidikan tidak terkecuali juga ketua Program studi.

Pendidikan di perguruan tinggi memiliki karakter yang berbeda dengan pendidikan dasar maupun menengah. Salah satu perbedaan itu adalah pada peran mahasiswa yang semakin besar dalam menentukan keberhasilan pendidikan mereka. Ilmu dan keterampilan yang didapat oleh mahasiswa lebih banyak bukan berasal dari materi dosen yang diajarkan di kelas. Keaktifan seorang mahasiswa akan menentukan seberapa banyak ilmu pengetahuan yang ia dapat dan juga seberapa ia berhasil menempa diri selama di bangku kuliah. Mahasiswa sebagai subjek pembelajaran di perguruan tinggi mestilah menjadi perhatian utama seluruh pelaksana pendidikan dalam rangka menjadikannya manusia yang memiliki kompetensi tinggi.

Di sinilah tugas ketua Program studi dalam memberikan kesempatan kepada para mahasiswa dengan menyediakan sebanyak mungkin wadah untuk menempa diri selain di dalam ruang kuliah. Kegiatan ekstrakulrikuler juga mestinya mendapat perhatian yang banyak dari ketua Program studi agar dapat menjadi tempat belajar yang baik bagi para mahasiswa selain di ruang kelas. Banyak sekali hal positif yang dapat dikembangkan melalui kegiatan ekstrakurikuler ini. Kebijakan ketua
Program studi yang tepat dan serius dapat menjadikan kegiatan ekstrakurikuler sebagai wadah yang sangat tepat bagi

mahasiswa menyalurkan minat, mengasah bakat, dan membentuk karakter dalam dirinya.

Melaui usaha tersebut, seorang mahasiswa akan memiliki banyak pilihan kegiatan yang dapat diikutinya untuk menempa diri menjadi manusia yang berkompeten. Selain dalam pendidikan formal, seorang mahasiswa juga dapat mengembangkan diri melalui kegiatan ekstrakurikuler. Ada banyak kegiatan ekstrakurikuler yang ditawarkan oleh sebuah perguruan tinggi yang dapat diikuti oleh setiap mahasiswa. Tidak sedikit mahasiswa yang setelah menyelesaikan pendidikan justru sukses melalui pengalamannya di kegiatan ekstrakurikuler yang pernah diikutinya dahulu. Hal ini menunjukkan bahwa kegiatan ekstrakurikuler memiliki peran yang penting dalam membentuk karakter mahasiswa tersebut. Ekstrakurikuler di perguruan tinggi di antaranya adalah Unit Kegiatan Mahasiswa (UKM) dan Himpunan Mahasiswa.

Dalam PP RI No. 232 Tahun 2000 tentang Pendidikan Tinggi Pasal 1 ayat 1 dijelaskan bahwa peran pendidikan tinggi dalam pembangunan pendidikan adalah sebagai lanjutan dari pendidikan menengah yang mempersiapkan peserta didik agar siap terjun ke masyarakat dengan memanfaatkan potensi diri dan keilmuan yang dimiliki. Selain itu, dalam pendidikan tinggi, peserta didik juga mengembangkan peradaban martabat bangsa melalui peningkatan kualitas keilmuan dan sumber daya manusia. Peserta didik disiapkan guna mengembangkan kemampuan akademik atau profesional yang dapat menerapkan, mengembangkan, dan menciptakan ilmu pengetahuan dan tekhnologi dan kesenian.

Dalam kaitannya dengan pendidikan karakter yang saat ini sedang digalakkan oleh pemerintah sekarang ini, pendidikan tinggi tentu juga memiliki peran yang besar dalam usaha untuk mensukseskannya. Dalam Peraturan Presiden Nomor 87 Tahun 2017 tentang Penguatan Pendidikan Karakter, pendidikan 
karakter bertujuan untuk membangun dan membekali Peserta Didik sebagai generasi emas Indonesia Tahun 2045 dengan jiwa Pancasila dan pendidikan karakter yang baik guna menghadapi dinamika perubahan di masa depan.

Karakter merupakan watak, tabiat, atau suatu kebiasaan yang dilakukan individu yang mengarah pada kebaikan-kebaikan (Komalasari \& Saripudin hlm. 1; Lickona, 2013, hlm. 81). Karakter mengacu pada serangkaian sikap, perilaku, motivasi, dan keterampilan. Karakter meliputi sikap seperti keinginan untuk melakukan hal yang terbaik, kapasitas intelektual seperti berpikir kritis, perilaku seperti jujur dan bertanggung jawab, mempertahankan prinsip-prinsip moral, kecakapan interpersonal dan emosional yang memungkinkan seseorang berinteraksi secara efektif dalam berbagai keadaan, dan komitmen untuk berkontribusi dengan komunitas dan masyarakatnya.

Perguruan tinggi memang sejatinya juga merupakan salah satu tempat untuk mempersiapkan generasi penerus bangsa yang berkarakter. Salah satu karakter yang sangat penting bagi seorang mahasiswa adalah karakter kepemimpinan. Oleh karena itu, perguruan tinggi memiliki ekstrakurikuler berupa organisasi kemahasiswaan yang berguna untuk mencetak calon-calon pemimpin masa depan. Karakter kepemimpinan sangat penting bagi mahasiswa untuk nantinya terjun di masyarakat. Seperti yang dikatakan oleh Engkoswara \& Komariah (2012, hlm. 178) bahwa pemimpin yang memiliki ciri kepemimpinan adalah seseorang yang memiliki kualitas diri yang baik tercermin dari sifat-sifat atau watak yang diharapkan oleh anggota dari pemimpinnya yaitu sifat cerdas, bijak, semangat, tanggung jawab, dan dapat dipercaya.

Setiap Program Studi di UNDIKMA terdapat organisasi mahasiswa yang menampung kegiatan kemahasiswaan di Program Studi tersebut. Dalam penelitian ini dapat dirumuskan beberapa rumusan masalah sebagai berikut.

$\begin{array}{ccc}\text { 1. Bagaimana } & \text { profil kegiatan } & \text { Himpunan } \\ \text { Mahasiswa } & \text { Program } & \text { Studi di }\end{array}$ Jurnal Ilmu Sosial dan Pendidikan

\section{UNDIKMA?}

2. Bagaimana peran ketua Program Studi dalam membentuk karakter kepemimpinan mahasiswa melalui kegiatan Himpunan Mahasiswa Program Studi di UNDIKMA?

3. Bagaimana cara membentuk karakter kepemimpinan mahasiswa melalui kegiatan Himpunan Mahasiswa Program Studi di UNDIKMA?

4. Apa sajakah karakter kepemimpinan yang dibentuk melalui kegiatan Himpunan Mahasiswa Program Studi di UNDIKMA?

\section{KAJIAN PUSTAKA}

\section{Definisi Pemimpin dan Kepemimpinan}

Pemimpin mempunyai macam-macam pengertian dari para ahli. Berikut ini terdapat beberapa definisi tentang pemimpin diantaranya : Menurut Amirullah (2015:2) Dalam bahasa Indonesia "pemimpin sering disebut penghulu, pemuka, pelopor, pembina, panutan, pembimbing, pengurus, penggerak, ketua, kepala, penuntun, raja, tua-tua dan sebagainya. Istilah pemimpin, kepemimpinan dan memimpin pada mulanya berasal dari kata dasar yang sama "pimpin". Namun demikian ketiganya digunakan dalam konteks yang berbeda. Pemimpin adalah suatu peran dalam sistem tertentu; karenanya seseorang dalam peran formal belum tentu memiliki keterampilan kepemimpinan dan belum tentu mampu memimpin.

Menurut Hasibuan (2011:157)

Pemimpin adalah seseorang yang mempergunakan wewenang dan kepemimpinannya untuk mengarahkan orang lain serta bertanggung jawab atas pekerjaan orang tersebut dalam mencapai suatu tujuan. Menurut Kartono (2010:18) Pemimpin adalah seorang pribadi yang memiliki kecakapan dan kelebihan, khususnya kecakapan dan kelebihan disatu bidang sehingga dia mampu mempengaruhi orang lain untuk bersamasama melakukan aktivitas-aktivitas tertentu demi pencapaian satu atau beberapa tujuan.

Definisi kepemimpinan dari para ahli adalah sebagai berikut : Kepemimpin berasal 
dari kata pimpin, menurut Veithzal Rivai (2003:2-4) Definisi kepemimpinan secara luas adalah meliputi proses mempengaruhi dalam menentukan tujuan organisasi, motivasi perilaku bawahan untuk mencapai tujuan, mempengaruhi untuk memperbaiki kelompok dan budayanya. Selain itu juga mempengaruhi interprestasi mengenai peristiwa-peristiwa para bawahannya, pengorganisasian dan aktivitasaktivitas untuk mencapai sasaran, memelihara hubungan kerjasama dan kerja kelompok, perolehan dukungan dan kerjasama dari orang-orang di luar kelompok atau organisasi. Kepemimpinan hanyalah sebuah alat, sarana atau proses untuk membujuk orang agar bersedia melakukan sesuatu secara suka rela atau sukacita. Ada beberapa faktor yang dapat menggerakkan orang yaitu karena ancaman, penghargaan, otoritas dan bujukan. Kepemimpinan adalah proses menggarahkan dan mempengaruhi aktivitas-aktivitas yang ada hubungannya dengan pekerjaan para anggota keompok. Tiga implikasi penting yang terkandung dalam hal ini yaitu: (1) kepemimpinan itu melibatkan orang lain baik itu bawahan ataupun pengikut, (2) kepemimpinan melibatkan pendistribusian kekuasaan antara pemimpin dan anggota kelompok secara seimbang, karena anggota kelompok bukanlah tanpa daya, (3) adanya kemampuan untuk menggunakan berbagai bentuk kekuasaan yang berbeda-beda untuk mempengaruhi tingkah laku bawahannya dengan berbagai cara.

Praktik kepemimpinan berkaitan dengan mempengaruhi tingkah laku dan perasaan orang lain baik secara individual maupun kelompok dalam arahan tertentu, sehingga melalui kepemimpinan merujuk pada proses untuk membantu mengarahkan dan memobilisasi orang atau ide-idenya. Sedangkan menurut Kartono (2010,5-8) Kepemimpinan merupakan salah satu relasi dan pengaruh antara pemimpin dengan yang dipimpin. Kepemimpinan tersebut muncul dan berkembang sebagai hasil dari interaksi otomatis antara pemimpin dengan orangorang yang dipimpinnya.

\section{Fungsi Pemimpin \& Kepemimpinan}

Jurnal Ilmu Sosial dan Pendidikan
Pemimpin memegang fungsi penting dalam sebuah organisasi. Menurut Sondang P. Siagian (2003:47) Karena kemampuan mengambil keputusan merupakan kriteria utama dalam menilai efektivitas kepemimpinan seseorang, berarti ada kriteria lain yang dapat dan biasanya digunakan. Berbagai kriteria itu berkisar pada kemampuan seorang pemimpin menjalankan berbagai fungsi-fungsi kepemimpinan. Lima fungsi-fungsi kepemimpinan yang dibahas secara singkat adalah sebagai berikut :

1. Pemimpin selaku penentu arah yang akan ditempuh dalam usaha mencapai tujuan,

2. Wakil dan juru bicara organisasi dalam hubungan dengan pihak-pihak diluar organisasi,

3. Pemimpin selaku komunikator yang efektif,

4. Mediator yang handal, khususnya dalam hubungan ke dalam, terutama dalam menangani situasi konflik,

5. Pimpinan selaku intergrator yang efektif, rasional, objektif dan netral.

\section{Karakteristik Pemimpin Melalui Pendekatan Sifat}

Berdasarkan riset yang telah dilakukan oleh kouzes \& posner (2004:2627) ada 20 karakteristik dari seorang pemimpin : (1). Jujur, (2). Berorientasi ke depan, (3). Kompeten, (4). Membangkitkan semangat, (5). Cerdas, (6). Berwawasan adil, (7). Berwawasan luas, (8). Mendukung, (9). Dapat dipercaya, (10). Dapat diandalkan, (11). Kooperatif, (12). Tegas, (13). Imajinatif, (14). Ambisius, (15). Berani, (16). Perhatian, (17). Dewasa, (18). Setia, (19). Pengendalian diri dan (20). Independen

\section{METODE PENELITIAN}

\subsection{Tahap-Tahap Penelitian}

Ada beberapa tahapan penelitian yang akan dilakukan oleh peneliti dalam penelitian ini, untuk lebih detail maka di bawah ini akan disampaikan secara rinci tahap-tahap penelitian dalam penelitian ini yaitu: (1) Peneliti mengajukan judul yang akan menjadi tema penelitian kepada LPPM UNDIKMA, (2) 
studi pendahuluan, untuk mengetahui issue yang urgen, unik menarik dan actual peneliti lakukan selama 12 hari yaitu pada tanggal 214 April 2020 yang kemudian dideskripsikan dalam bentuk proposal, (3) Melaksanakan kegiatan penelitian dan, (4) Membuat laporan hasil penelitian.

\subsection{Lokasi Penelitian}

Penelitian ini dilaksanakan di UNDIKMA.

\subsection{Pendekatan dan Jenis Penelitian}

Metode penelitian yang digunakan adalah metodologi penelitian deskriptif dengan pendekatan deskriptif kualitatif. Subjek penelitian adalah seluruh Himpunan Mahasiswa Program Studi yang ada di UNDIKMA. Teknik pengumpulan data yang digunakan ada empat tahapan, mengikuti teori dari Sugiyono (2016, hlm. 309) yaitu: (1) teknik observasi, digunakan untuk mengumpulkan data berupa profil kegiatan Himpunan Mahasiswa Departemen; (2) teknik wawancara, digunakan untuk mengumpulkan data dari ketua departemen, dosen pembimbing himpunan, dan pengurus dan anggota himpunan (mahasiswa); (3) teknik dokumentasi, digunakan untuk mengumpulkan data/ berkas yang berkaitan dengan kegiatan himpunan; dan (4) teknik triangulasi (gabungan), digunakan untuk mengetahui data yang diperoleh convergen (meluas), tidakk konsisten atau kontradiksi. Melalui teknik triangulasi, maka data yang diperoleh akan lebih konsisten, tuntas, dan pasti.

Sumber data penelitian yang digunakan adalah informan, sarana dan prasarana yang ada di lingkungan Himpunan dan sumber data yang berupa simbol, seperti latar belakang himpunan, visi, misi dan tujuan himpunan, dan kegiatan yang dilakukan pada saat pelaksanaan kegiatan himpunan. Informan yang dijadikan sumber data dalam penelitian merupakan informan yang terkait langsung dengan penelitian dan memahami situasi dan kondisi yang diteliti. Adapun informan yang dijadikan sumber data adalah sebagai berikut: (1) Ketua Program Studi, dan (2) Pengurus dan anggota himpunan (mahasiswa).

Teknik pengumpulan data yang digunakan dalam penelitian ini adalah Jurnal Ilmu Sosial dan Pendidikan observasi, wawancara, dan dokumentasi. Analisis data dalam penelitian ini dilakukan sebelum peneliti memasuki lapangan, pada saat pengumpulan data berlangsung dan setelah selesai pengumpulan data. Analisis masalah penelitian yang dilakukan ini untuk menjawab pertanyaan penelitian mengenai peran ketua Program Studi dalam kegiatan Himpunan Mahasiswa Program Studi. Analisis data penelitian ini menurut Milles dan Hubermant (2007), diantaranya reduksi data, penyajian data dan penarikan kesimpulan. Dalam penelitian ini, yang lebih dipertimbangkan adalah menggunakan teknik wawancara kualitatif. Metode wawancara yang digunakan dalam penelitian ini adalah wawancara langsung, berupa interview secara mendalam kepada informan penelitian. Wawancara adalah percakapan dengan maksud tertentu. Percakapan itu dilakukan oleh dua pihak, yaitu pewawancara yang melakukan pertanyaan dan yang diwawancara memberikan jawaban atas pernyataan itu (Moleong, 2002, hlm. 135). Wawancara digunakan sebagai teknik pengumpulan data apabila peneliti ingin melakukan studi pendahuluan menemukan suatu masalah yang ingin diteliti, tetapi juga apabila ingin mengetahui hal dari narasumber yang mendalam (Sugiyono, 2011, hlm. 231).

\section{HASIL DAN PEMBAHASAN HASIL PENELITIAN}

Profil Badan Eksekutif Mahasiswa Universitas Pendidikan Mandalika Organisasi mahasiswa untuk mengikuti kegiatan non akademik (ekstra kurikuler) yang diwadahi dalam berbagai jenis organisasi kemahasiswaan seperti Dewan Perwakilan Mahasiswa (DPM), Badang Eksekutif Mahasiswa (BEM), dan Unit Kegiatan Mahasiswa (UKM). Organisasi kemahasiswaan berkedudukan di Universitas dan Fakultas di Lingkungan Universitas Pendidikan Mandalika Mataram. Mahasiswa Universitas Pendidikan Mandalika Mataram yang tergabung dalam organisasi kemahasiswaan, diharapkan mampu mempersiapkan diri dalam menghadapi era baru dengan keterampilan manajemen, komunikasi 
dan kepemimpinan. Organisasi kemahasiswaan memiliki peran penting dalam membentuk kepribadian, karakter, watak yang berwawasan luas sebagai penyiapan tenaga profesional dalam bidangnya. Mahasiswa sebagai salah satu komponen civitas akademika Universitas Pendidikan Mandalika Mataram memiliki karakteristik yang heterogen, kedudukan dan fungsinya yang sangat strategis perlu dibina dan dikembangkan. Mereka sebagai Sumber Daya Manusia (SDM) yang cukup potensial perlu ditingkatkan daya kreativitasnya agar kelak menjadi lulusan yang sesuai dengan tujuan diselenggarakan pendidikan di Universitas Pendidikan Mandalika Mataram dan tujuan Pendidikan Nasional. Untuk mencapai tujuan tersebut tentunya memerlukan strategi yang dilakukan oleh bidang kemahasiswaan, yang meliputi suasana kampus yang kondusif dalam bentuk kegiatan kurikuler, ko-kurikuler dan ekstrakurikuler yang utuh. (Buku Pedoman Organisasi Mahasiswa).

Tujuan utama pelayanan akademik baik dalam bentuk kurikuler maupun ko-kurikuler adalah mengantarkan mahasiswa mencapai tingkat kesarjanaan, sedangkan pembinaan dan pengembangan mahasiswa dalam bentuk ekstrakurikuler guna mematangkan kepribadian mahasiswa sesuai dengan potensi yang dimiliki dan untuk melahirkan lulusan yang sesuai dengan cita-cita Universitas Pendidikan Mandalika Mataram dengan Visi, Misi, dan Tujuan Pembinaan Organisasi Mahasiswa "Visi Menjadikan pola pembinaan kemahasiswaan berbasis karakter, intelektualitas dan entrepreneurship". Misi 1. Menyelenggarakan pembinaan kemahasiswaan melalui Kegiatan Kemahasiswaan 2. Menyelenggarakan pembinaan kemahasiswaan yang mengembangkan jiwa kewirausahaan (enterpreneurship). Tujuan Umum Secara umum pembinaan kemahasiswaan ditujukan untuk membentuk Mahasiswa akademisi yang berkarakter, inovasi dan memiliki jiwa kewirausahaan. Tujuan Khusus 1. Terbinanya suasana kehidupan Kampus yang harmonis dan kondusif bagi pengembangan nilai moralitas, intelektualitas dan berjiwa entrepreneurship. 2 .
Terbinanya generasi penerus yang berkarakter dan mandiri.

\section{A. Struktur Organisasi}

Organisasi kemahasiswaan (ormawa) merupakan wahana pengembangan diri mahasiswa yang diharapkan dapat meningkatkan penalaran dan keilmuan serta arah profesi mahasiswa, menampung kebutuhan, menyalurkan minat dan kegemaran, meningkatkan kesejahteraan, meningkatkan kemampuan kewirausahaan. Organisasi mahasiswa yang ada di Universitas Pendidikan Mandalika Mataram meliputi: 1. Tingkat Universitas a. Dewan Perwakilan Mahasiswa (DPM). b. Badan Eksekutif Mahasiswa (BEM). c. Unit Kegiatan Mahasiswa (UKM). 2. Tingkat Fakultas a. Dewan Perwakilan Mahasiswa Fakultas (DPM-F). b. Badan Eksekutif Mahasiswa Fakultas (BEM-F). 3. Tingkat Program Studi/Jurusan: Himpunan Mahasiswa Program Studi (HMPS). 4. Antar-perguruan tinggi terdapat: Ikatan Organisasi Mahasiswa Sejenis (IOMAS) yang meliputi ikatan mahasiswa sejenis yang ada di Universitas Pendidikan Mandalika Mataram.

\section{B. Tugas dan Fungsi Organisasi Mahasiswa}

Organisasi mahasiswa merupakan wadah para mahasiswa untuk berproses baik dalam pembelajaran dan pendidikan yang diperoleh melalui program kegiatan yang dilaksanakan secara formal maupun non formal. Organisasi Mahasiswa (ORMAWA) Universitas Pendidikan Mandalika terbagi menjadi organisasi tingkat Universitas, Fakultas dan Program Studi. Seacara umum ORMAWA berfungsi sebagai penghubung komunikasi antar mahasiswa, wadah untuk pengembangan potensi mahasiswa sebagai insanakademis yang berpengetahuan luas serta berguna bagi bangsa dan negara, pengembangan intelektual, pelatihan kepemimpinan dan managemen organisasi. Selain itu, ORMAWA juga berperan dalam pembinaan dan pengembangan kaderkader agama dan bangsa yang berorientasi dalam melanjutkan kesinambungan pembagunan nasional, pemeliharaan dan pengembangan ilmu dan keagamaan yang dilandasi oleh norma akademis, etika, moral dan 
wawasan kebangsaan.

a. Dewan Perwakilan Mahasiswa (DPM)

1. Mematuhi Kode Etik Mahasiswa dan Pedoman Kegiatan Mahasiswa UNDIKMA Mataram. 2. Menentukan Visi dan Misi Organisasi Mahasiswa di Lingkungan IKIP Mataram yang disesuaikan dengan Visi dan Misi UNDIKMA Mataram. 3. Membuat Ketetapan Garis-garis Besar Haluan Kerja Organisasi Mahasiswa sesuai dengan Visi dan Misi IKIP Mataram. 4. DPM UNDIKMA Mataram menetapkan mekanisme Pemilihan Umum Raya Mahasiswa (Pemilu Raya) tingkat Universitas dan DPM Fakultas akan menetapkan mekanisme Pemilihan Umum Raya (Pemilu Raya) tingkat Fakultas. 5. DPM Intitut mengawasi organisasi mahasiswa di tingkat Universitas dan DPM Fakultas mengawasi organisasi mahasiswa di tingkat Fakultas. 6. DPM Universitas membuat laporan pertanggungjawaban kegiatan dan kepengurusan kepada Wakil Rektor I dan DPM Fakultas membuat laporan pertanggungjawaban kegiatan dan kepengurusan kepada Wakil Dekan I.

b. Badan Eksekutif Mahasiswa (BEM)

Mematuhi Kode Etik Mahasiswa dan Pedoman Kegiatan Mahasiswa UNDIKMA Mataram. 2. BEM Intitut dan Fakultas menjalankan Ketetapan Garis-garis Besar Haluan Kerja yang ditetapkan DPM. 3. BEM Universitas dan Fakultas Membuat program kerja terutama yang berhubungan untuk pengembangan karakter diri, kepemimpinan dalam berorganisasi. 4. BEM Intitut melakukan koordinasi atas program kerja masing-masing UKM di Universitas dan BEM Fakultas melakukan koordinasi atas program kerja masing-masing UKMF dan HMPS. 5. BEM Universitas membentuk Komisi Pemilu Raya Mahasiswa (KPRM) tingkat Universitas dan BEM Fakultas membentuk Komisi Pemilu Raya Mahasiswa (KPRM) tingkat Fakultas. 6. BEM Universitas dan Fakultas membuat laporan pertanggungjawaban kegiatan dan kepengurusan kepada Dewan Perwakilan Mahasiswa sesuai peraturan dari KPRM.

\section{c. Unit Kegiatan Mahasiswa (UKM)}

1. Mematuhi Kode Etik Mahasiswa dan Pedoman Kegiatan Mahasiswa UNDIKMA Mataram. 2. Membuat program kerja terutama yang berhubungan dengan minat, bakat dan kegemaran. 3. Melaksanakan kegiatan sesuai program kerja. 4. UKM Universitas membuat laporan pertanggungjawaban kegiatan dan kepengurusan kepada Wakil Rektor I dan UKM Fakultas membuat laporan pertanggungjawaban kegiatan dan kepengurusan kepada Wakil Dekan I.

d. Himpunan Mahasiswa Program Studi (HMPS)

1. Mematuhi Kode Etik Mahasiswa dan Pedoman Kegiatan Mahasiswa UNDIKMA Mataram. 2. Menjalankan Ketetapan Garisgaris Besar Haluan Kerja yang ditetapkan DPM Fakultas. 3. Membuat Program Kerja terutama yang berhubungan dengan penalaran kelimuan dan keahlian. 4. Melaksanakan kegiatan sesuai program kerja. 5. Melaksanakan koordinasi dengan BEM dan DPM Fakultas atas program kerjanya. 6. HMJ membuat laporan pertanggungjawaban kegiatan dan kepengurusan kepada Wadek I.

Arah pengembangan pembinaan kemahasiswaan sesuai dengan Buku Pedoman Organisasi Mahasiswa Universitas Pendidikan Mandalika memiliki tujuan dalam rangka peningkatan kualitas mahasiswa dan lulusan sebagai berikut :

\section{Ruang Lingkup Pembinaan}

Ruang lingkup pembinaan kemahasiswaan meliputi: 1 ). Bidang penalaran/keahlian/keprofesian, 2). Bidang minat, bakat, dan atau keorganisasian. 3) Bantuan dana Pendidikan dan kesejahteraan mahasiswa, 4) Kapasitas organisasi 5) Orientasi Studi/Program Pengenalan Kehidupan Kampus Mahasiswa Baru (PKMB)

2. Program Bantuan Dana Pendidikan Dan Kesejahteraan Mahasiswa (Beasiswa)

Program ini dimaksudkan untuk membantu meningkatkan kesejahteraan bagi mahasiswa yang kurang mampu ekonominya namun berprestasi akademik. Ada beberapa jenis 
yaitu Peningkatan Prestasi Akademik (PPA), Bantuan Belajar Mahasiswa (BBM) dan Bidikmisi. Program ini dimaksudkan untuk memacu prestasi akademik dan keteladanan/kepeloporan mahasiswa di berbagai segi baik keilmuan, penalaran, budi pekerti, agama, maupun kepemimpinan dan manajemen sekaligus memberikan penghargaan dan kesejahteraan bagi mereka

3. Program Pengembangan Kepemimpinan dan Managemen.

Program ini sangat penting untuk menumbuh kembangkan potensi kepemimpinan dan manajemen di kalangan mahasiswa agar kelak siap terjun di masyarakat dengan mantap, peka, penuh kreativitas dan inisiatif. Program ini dilakukan dalam bentuk pelatihan kepemimpinan dan manajemen antara lain latihan dasar kepemimpinan di tingkat dasar, menengah, dan lanjutan; Latihan Retorika dan Protokoler, dan sebagainya.

4. Pengembangan Ikatan Organisasis Mahasiswa Sejenis (IOMS) dan Organisasi Mahasiswa Antar-kampus.

Program ini dimaksudkan untuk menanamkan sikap ilmiah, pemahaman tentang arah profesi dan sekaligus meningkatkan kerjasama, rasa persatuan nasional dan bahkan terciptanya saling pengertian di kalangan mahasiswa di tingkat regional maupun internasional, disamping memperluas wawasan kemampuan berorganisasi di kalangan mahasiswa. Seperti contoh: 1) Pergerakan Mahasiswa Islam Indonesia ( PMII ) 2) Ikatan Mahasiswa Biologi Indonesia (IMBI) 3) Ikatan Senat Mahasiswa Psikologi Indinesia (ISEMAPSI)

\section{PEMBAHASAN}

a. Peran Ketua Program Studi dalam Membentuk Karakter Kepemimpinan melalui Kegiatan Himpunan Mahasiswa Program Studi

Kegiatan Penelitian yang dilakukan fokus pada kegiatan pembentukan karakter kepemimpinan orgaanisasi mahasiswa dari beberapa focus kegiatan pembinaan organisasi kemahasiswa yang dilakukan atau direncanakan oleh lembaga secara umum.

Fokus penelitian ini terkait dengan kemampuan mahasiswa dan alumni secara umum dalam melaksanakan/menyelesaikan tugas perkuliahan dan kinerja bagi alumni yang dimana pembinaan teknisnya pada program studi sebagai eksekusi lapangan/langsung. Peran ketua Program Studi dalam pembahasan pada bagian ini lebih spesifik pada peran dalam Tanggungjawab, disiplin, kejujuran, perencanaan, bentuk partisipasi, komunikasi, delegasi, dan evaluasi yang dilakukan ketua Program Studi pada kegiatan himpunan mahasiswa ditingkat Program Studi dan Fakultas.

Dari beberapa pendapat narasumber di Program Studi Universitas Pendidikan Mandalika Mataram dalam wawancara dan penyebaran angket berkaitan dengan bagaimana peran ketua Program Studi dalam menyusun penyusunan aturan-aturan yang sepakati pengurus dan anggota yang dibuat oleh Ketua Program studi dengan HMJ dapat disimpulkan bahwa aturan secara umum telah tertuang dalam Buku Pedoman Organisasi Mahasiswa ditingkat Universitas dan ditingkat program studi Ada, aturan-aturan tersebut tertuang dalam AD/ART dan GBPK yang disusun secara bersama antara organisasi mahasiswa dengan Program studi dan sudah dilaksanakan. Kegiatan penyusunan aturan dimana program studi memiliki peran yang cukup baik. Aturan dirancang oleh pengurus terlebih dahulu, kemudian dikoordinasikan kepada ketua program studi sebagai pihak yang memberikan pertimbangan dan persertujuan. Ketua Program Studi dalam menjalankan fungsinya ini bersama-sama dengan pengurus himpunan mahasiswa.

Bagaimana bentuk komunikasi HMJ dengan ketua Program Studi. Komunikasi HMPS dengan Program studi berjalan dengan baik. Karena HMPS setiap akan merancang program kerja dan TOR selalu berkomunikasi dengan prodi, setiap kegiatan yang akan dilaksanakan maupun setelah selesai kegiatan HMPS selalu berkoordinasi dengan Prodi. 
Harapannya adalah agar program kerja yang dilaksanakan oleh HMPS sejalan dengan Prodi. Ada beberapa kegitan yang selalu ditekankan oleh prodi kepada HMPS, yakni agar kegiatannya selalu bermuatan penambahan kompetensi mahasiswa dalam menunjang SKPI, sosialisasi dan pengabdian (bakti sosial)

Berdasarkan hasil wawancara berkaitan dengan komunikasi dengan ketua Program Studi dalam kegiatan himpunan di Mahasiswa, dapat disimpulkan bahwa ketua Program Studi melakukan komunikasi yang baik dalam setiap kegiatan. Komunikasi yang dilakukan antara ketua Program Studi maupun dengan Himpunan Mahasiswa disesuaikan dengan kebutuhan apa yang akan dikomunikasikan. Jika berkaitan dengan kemahasiswaan, pengurus lebih berkomunikasi dengan Ketua Program Studi kemudian dilanjutkan ke tingkat Fakultas. Seperti Bagan Berikut :

ALUR KOMUNIKASI ANTARA KETUA PROGRAM STUDI DAN HIMPUNAN MAHASISWA PRODI

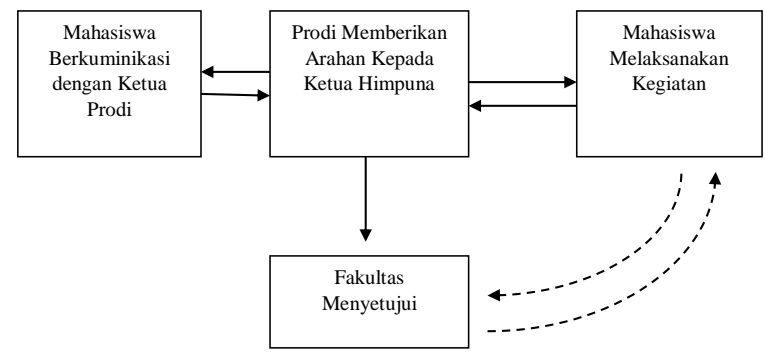

Bagan Proses Kuminikasi Ketua Program Studi dan Himpunan Mahasiswa

Peran prodi dalam penyusunan visi, misi HMJ dan apakah disesuaikan dengan visi, misi prodi. Prodi mensosialisasikan visi misi nya kepada HMPS, dan visi misi HMPS adalah turunan dari visi misi Program Studi. Dari hasil wawancara dan angket didapatkan informasi bahwa kegiatan penyusunan visi, misi dan tujuan himpunan mahasiswa, merupakan suatu kesatuan atau turunan dari visi misi fakutas dan program studi. Kegiatan penyusunan visi misi bermula dari atau didasari dari visi misi fakultas yang kemudian diturunkan menjadi visi misi program studi. Program studi melakukan kegiatan sosialisasi visi misi kepada himpunan mahasiswa Jurnal Ilmu Sosial dan Pendidikan yang akan dijadikan dasar atau sumber utama dalam penyusunan visi misi. Proses penyusunan visi misi dimana ketua himpunan membentuk tim penyusunan visi misi sehingga diproses sebuah visi misi yang dijadikan pedoman dalam melakukan kegiatan pengembangan dan proses penyusunan perencanaan kegiatan. Visi misi yang telah disusun oleh himpunan mahasiswa diajukan kepada ketua program studi untuk dilakukan pengkajian dan mendapatkan persetujuan dari ketua program studi. Visi misi yang telah disusun dan telah disepakati bersama antara Himpunan mahasiswa dan ketua program studi kemudian diajukan untuk pengesahan atau penetapan oleh fakultas.
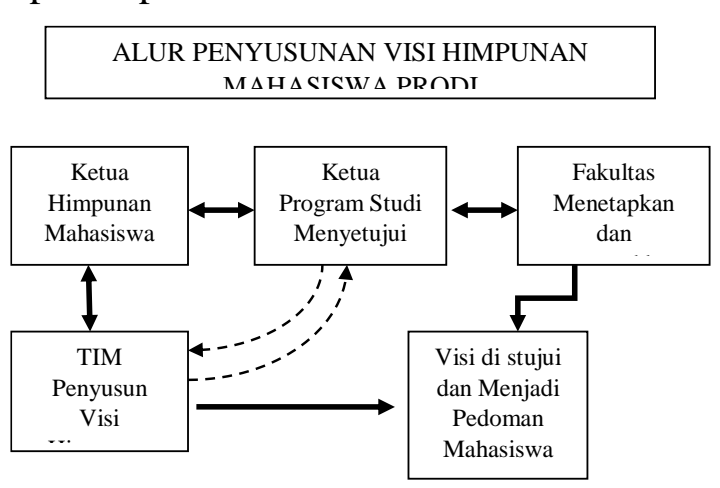

Bagan Proses Penyusunan Visi Misi Himpunan

Peran prodi dalam menyusun program kerja HMJ dan apakah disesuaikan dengan program kerja Prodi. Program Studi melakukan pembinaan kepada HMPS. Setiap akan merancang program HMPS selalu berkoordinasi dengan Prodi, kemudian setiap bulan ke 4 di semester pertama prodi akan mengajak HMPS untuk berkoordinasi lagi dan memberikan evaluasi terkait kegiatan yang telah dilakukan serta melakukan analisis ancaman dan hambatan jika program yang direncanakan tidak berjalan sambil melakukan perancangan untuk program2 yang akan dilaksanakan di semester berikutnya.

Peran ketua Program Studi dalam menyusun rencana program kerja dalam kegiatan himpunan. Ketua Program Studi mengadakan pertemuan dengan HMPS untuk membicarakan perencanaan program kerjanya. Selain itu juga memberikan masukan terkait dengan rencana kerja HMPS. Adapun hasil wawancara dari beberapa pendapat narasumber di Program Studi 
dalam wawancara berkaitan dengan bagaimana peran ketua Program Studi dalam perencanaan program kerja kegiatan himpunan di atas, bahwa ketua Program Studi, Himpunan Mahasiswa memiliki peran yang cukup baik dalam perencanaan program kerja. Program kerja disusun terlebih dahulu oleh pengurus dan selalu didukung dan difasilitasi oleh ketua Program Studi. Program kerja yang disepakati sebelumnya dilakukan penyelarasan terlebih dahulu antara program kerja himpunan mahasiswa dengan program kerja prodi. Penyelarasan ini bertujuan agar antara program kerja himpunan mahasiswa dan program kerja Program Studi sejalan. Cara kerja kedua departemen ini memiliki kesamaan yaitu ketua Program Studi berperan sebagai pasilitator, pertimbangan dan penyelaras program kerja yang disusun oleh pengurus himpunan.

Proses perencanaan kegiatan pada kedua Himpunan sudah terbilang baik. Karena ketua Program Studi sebagai pimpinan tertinggi di program studi mengetahui dan mengikuti proses terbentuknya dari awal sampai pada goalnya. Seperti yang dijelaskan oleh Wahjosumidjo 2001. bahwa merencanakan (planning), adalah kepala sekolah harus benar-benar memikirkan dan merumuskan dalam suatu program tujuan dan tindakan yang harus dilakukan. Dalam hal ini posisi kepala sekolah di instansi adalah ketua. Sedangkan menurut George R. Tery (dalam Karwati \& Priansa:2013, juga demikian bahwa dari segi perencanaan (planning) kepala sekolah harus mampu melaksanakan perencanaan. Perencanaan adalah sebagai penentuan terlebih dahulu apa yang harus dikerjakan, kapan dikerjakan, dan siapa yang mengerjakannya. Dalam perencanaan terlibat pengambilan keputusan oleh kepala sekolah. Oleh karena itu, perencanaan dapat dilihat sebagai suatu proses pengambilan keputusan dan penyusunan rangkaian tindakan yang akan dilakukan. Rencana yang baik akan merumuskan tujuan dan sasaran yang ingin dicapai oleh sekolah.

$$
\text { Terkait dengan memfasilitasi, }
$$

Persetujuan, terlibat baik itu membuka atau menutup kegiatan HMJ dalam melaksanakan program kerja. Program studi selalu menfasilitasi HMPS jika menemui permasalahan dan Jurnal Ilmu Sosial dan Pendidikan hambatan dalam menjalankan programnya, jika tidak bisa ditanggulangi maka ka prodi akan berkoordinasi dengan Wakil dekan I. Pelaksanakan kegiatan harus mendapatkan persetujuan dari Ketua Program Studi. karena HMPS bertanggung jawab terhadap Ka Prodi sesuai dengan garis koordinasi. Kegiatan yang dilaksanakan oleh HMPS selalu di buka oleh Ka Prodi. Partisipasi dalam hal ini adalah bagaimana $\mathrm{k} € \begin{gathered}\text { ALUR PENYUSUNAN PROGRAM KERJA HIMPUNAN } \\ \text { MAHASISWA }\end{gathered}$ pelaksanaan kegiatan- kegiatan yang $\begin{gathered}\text { Ketua Himpunan } \\ \text { Mahasiswa }\end{gathered}$
 $\begin{gathered}\text { Ketua } \\ \text { Program Studi }\end{gathered}$ pun $\begin{gathered}\text { Fakultas } \\ \text { Menetapkan dan }\end{gathered}$

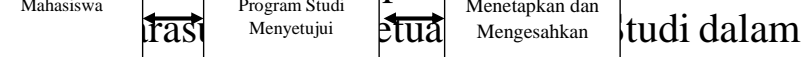
keghatan himpuṇăn, dapat d1kimpulkan bahwa

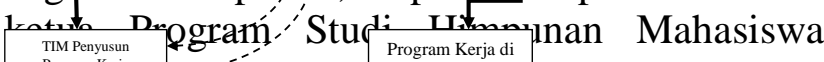

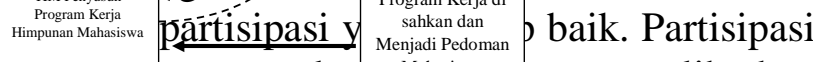

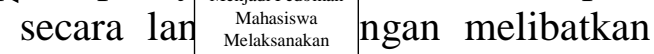
unsur nimninan di tinokat Fakultas, ketua ......... Bagan Proses Perencanaan Program Kerja $\ldots . . . . . . . \quad$ dalam membuka dan menutup kegiatan. Dalam beberapa kesempatan terkadang juga mengikuti kegiatan secara penuh. Hal tersebut disesuaikan dengan kesibukan maupun ketika ada tugas lain di luar kegiatan yang berkaitan dengan kegiatan mahasiswa. Secara keseluruhan, ketua Program Studi tetap ikut berpartisipasi dan mengetahui bagaimana perkembangan dari perencanaan kegiatan sampai pada pelaksanaan kegiatan melalui Ketua Himpunan Mahasiswa.

Komponen selanjutnya yang diteliti dalam rangka mengukur peran ketua Program Studi dalam membentuk karakter kepemimpinan mahasiswa melalui kegiatan himpunan mahasiswa adalah peran dalam hal delegasi. Delegasi dalam hal ini berkaitan dengan penyerahan atau pelimpahan wewenang yang terjadi antara ketua Program Studi dan mahasiswa sebagai pengurus himpunan. 
Berdasarkan hasil wawancara berkaitan dengan pola delegasi yang dilakukan dalam kegiatan himpunan, dapat disimpulkan bahwa ketua Program Studi melakukan delegasi berdasarkan dalam bentuk kebutuhan. Ketika delegasi harus dilakukan langsung dari pihak Ketua Program Studi kepada mahasiswa, saat itu juga dilakukan delegasi tersebut. Namun, jika harus melalui Unsur Pimpinan ditingkat Fakutas, ketua Program Studi mengkomunikasikan dan berkoordinasi terlebih dahulu denganWakil Dekan I. Hal tersebut dilaksanakan sesuai dengan garis koordinasi yang terdapat dalam struktur kepengurusan Himpunan Mahasiswa.

Dari bagan pola delegasi di atas, yang ada dalam kedua kegiatan himpunan sudah terbilang baik. Seperti yang dikatakan oleh (Keating, Charles J., hlm. 1991) bahwa delegasi (delegation) adalah pemberian sebagian tanggung jawab dan kewi bawaan kepada orang lain. Kemudian P Jenks (1991, hlm. 45) juga mengatakan bahwa menjadi seorang delegator yang baik adalah merupakan suatu proses belajar maupun sebagai suatu cara untuk memperoleh hasil yang spesifik. Hal tersebut sama halnya yang terjadi pada pendelegasian dari ketua program studi kepada dosen pembimbing maupun kepada mahasiswa Himpunan, mereka melakukan pola delegasi yang sesuai dengan kebutuhan dan bertujuan untuk tercapainya tujuan organisasi.

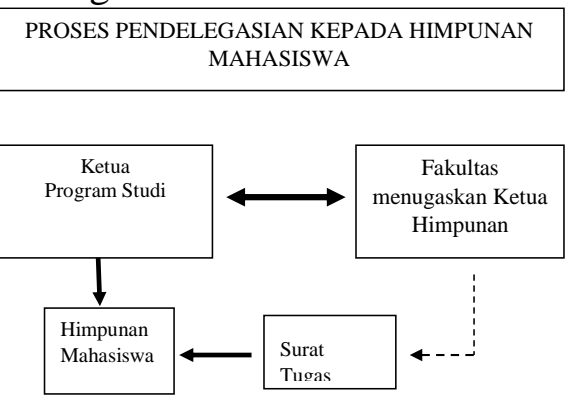

Bagan Pendelegasian Ketua Program Studi ke HMPS

Komponen terakhir yang diteliti dalam rangka mengukur peran ketua Program Studi dalam membentuk karakter kepemimpinan mahasiswa melalui kegiatan himpunan mahasiswa adalah peran dalam hal Laporan dan evaluasi. Evaluasi berkaitan dengan pengukuran Jurnal Ilmu Sosial dan Pendidikan kinerja atas kegaitan yang telah dikerjakan oleh himpunan. Berdasarkan hasil wawancara berkaitan dengan evaluasi yang dilakukan oleh ketua departemen dalam kegiatan himpunan dapat disimpulkan bahwa ketua departemen melakukan evaluasi yang cukup baik dalam setiap kegiatan. Di mana, evaluasi yang dilakukan biasanya dalam bentuk forum diskusi. Diskusi dilakukan tidak harus berdasarkan adanya program/jadwal, tapi lebih kepada tingkat kebutuhan diskusi/ evaluasi pada saat itu sehingga sering kali pertemuan direncanakan secara men dadak. Selain itu, evaluasi juga ditunjukan untuk memberikan kebebasan berkreasi dan berfikir kreatif dalam menjalankan program kerja dengan tidak keluar dari aturan akademik dan organisasi himpunan. Hal tersebut dilakukan agar dari hasil evaluasi dapat dipersiapkan kembali kegiatan-kegiatan yang sesuai dengan masukan atau hasil evaluasi pada kegiatan sebelumnya.

Adapun hasil wawancara berkaitan dengan evaluasi yang dilakukan oleh ketua Program Studi, dapat disimpulkan bahwa ketua departemen juga melakukan evaluasi yang cukup baik dalam setiap kegiatan. Di mana, evaluasi dilaksanakan dalam bentuk laporan per tanggungjawaban. Laporan pertanggungjawaban tersebut meliputi laporan per kegiatan dan laporan masa jabatan pada saat pergantian pengurus himpunan. Selain itu, kegiatan evaluasi juga dilakukan setelah kegiatan dilaksanakan melalui forum diskusi dengan ketua himpunan dan panitia pelaksana. Diskusi biasanya dilakukan secara informal dengan tujuan agar pengurus dan panitia tidak merasa dihakimi oleh ketua Program Studi dalam mempertanggungjawabkan kinerjanya. Bentuk evaluasi yang dilakukan ketua Program Studi dapat digambarkan sebagai berikut. Dari bagan proses evaluasi di atas yang dilakukan dalam himpunan sudah sangat baik. Seperti yang dikatakan oleh (Komalasari \& Saripudin, 2017) bahwa dalam organisasi dilaksanakan melalui empat mekanisme yaitu 1) Pengembangan, dalam mekanisme pengembangan suatu kegiatan dalam organisasi dapat dilakukan dengan empat tahap; 2) Pelaksanaan, penjadwalan kegiatan dirancang 
di awal tahun oleh pem- bina di bawah pimpinan tertinggi dalam or- ganisasi. Jadwal kegiatan diatur agar tidak menghambat pelaksanaan kegiatan yang lain, 3) Penilaian, penilaian dilakukan dilihat dari sudut pandang keberhasilan yaitu meli- puti proses dan pencapaian kinerja para pengurus organisasi, dan 4) Evaluasi, evaluasi kegiatan dilakukan untuk mengukur ketercapaian tujuan pada setiap indikator yang telah ditetapkan dalam perencanaan kegiatan. Berkaitan dengan itu, evaluasi yang dilakukan oleh ketua departemen dalam setiap kegiatan telah dilakukan dengan baik. Di mana ketua departemen selalu memantau perkembangan dan tingkat ketercapaian masing-masing kegiatan yang telah diprogramkan.

Dari 13 peran ketua program tersebut yakni meliputi Penataan, Pengembangan, perencanaan, fasilitas, partisipasi, komunikasi, delegasi, evaluasi, pelaporan, yang dilakukan ketua Ketua Program Studi teradap kegiatan Himpunan Mahasiswa dapat disimpulkan bahwa ketua Program Studi masing-masing memiliki peran di dalamnya. Porsi dari peran keduanya disesuaikan dengan tingkat kebutuhan pada saat dibutuhkan dan disesuaikan dengan situasi dan kondisi yang ada. Sebagai pemegang tanggung jawab secara keseluruhan berperan sebagai pengarah sebagai ujung tombak pengawasan dan pembinaan di lapangan. Namun pada beberapa kesempatan, ketua Program Studi ikut turun langsung memberikan arahan mahasiswa dan turut bersama-sama dalam kegiatan himpunan.

\section{A. Strategi, Program Pengembangan pembentuk Karakter Kepemimpinan Mahasiswa melalui Kegiatan Himpunan Mahasiswa Program Studi}

\section{Strategi Pembentukan Karakter Kepemimpinan}

Program ini dilakukan dalam bentuk pelatihan kepemimpinan dan manajemen antara lain latihan dasar kepemimpinan di tingkat dasar, menengah, dan lanjutan; Latihan Retorika dan Protokoler, dan sebagainya

Dengan memperhatikan komponen dan potensi pengembangan kemahasiswaan dan hakikat pendidikan tinggi sebagai masyarakat dan lembaga ilmiah, serta menyadari bahwa pengembangan kemahasiswaan merupakan pelengkap kegiatan kurikuler dalam mewujudkan tujuan pendidikan nasional, perlu disusun strategi pengembangan kemahasiswaan UNDIKMA dari hasil wawancara dengan ketua program studi sebagai berikut:

Meningkatkan Pembinaan dan Kualitas Wawasan, Profesionalitas, Keterampilan Keilmuan dan (Hard Skills) Mahasiswa, dengan indikator: Meningkatkan pembinaan dan kualitas mahasiswa berprestasi di tingkat nasional; Meningkatkan pembinaan dan kualitas inovasi, kreativitas, daya nalar, penulisan ilmiah dan karya cipta ilmiah mahasiswa; Meningkatan pembinaan dan kualitas wawasan keilmuan, pengembangan teknologi, dan penguasaan teknologi informasi mahasiswa; Meningkatkan pembinaan kegiatan dalam rangka menumbuhkan kepekaan sosial dan profesionalitas mahasiswa dalam menjawab masalah nyata di lapangan yang relevan dengan bidang ilmu yang ditekuni; Meningkatkan pembinaan dalam mengembangkan kemampuan intelektual mahasiswa di forum-forum ilmiah mahasiswa tingkat nasional dan internasional.

Meningkatkan Pembinaan dan Kualitas Keterampilan Lunak (Soft Skills) Mahasiswa, dengan indikator: Meningkatkan pembinaan dan kualitas program pengembangan konsep diri, pengelolaan diri, rasa empati, dan pergaulan sosial mahasiswa; Meningkatkan pembinaan dan kualitas pengembangan visi dan strategi kepemimpinan mahasiswa; Meningkatkan pembinaan dan kualitas pengembangan wawasan kebangsaan mahasiswa; Meningkatkan pembinaan dan kualitas pengembangan budaya organisasi mahasiswa; Meningkatkan pembinaan dan kualitas program pemberian bimbingan/konseling kepada mahasiswa. Meningkatan pembinaan dan kualitas prestasi olahraga mahasiswa; Meningkatkan pembinaan dan kualitas ketertarikan dan kepedulian mahasiswa pada masalah lingkungan.

Meningkatkan Kesejahteraan Mahasiswa, dengan indikator: Meningkatkan kualitas hidup dan prestasi akademik mahasiswa dengan latar belakang khusus (ekonomi lemah, aktif 
berorganisasi, prestasi akademik yang baik, dll.) melalui pemberian beasiswa, program kerjasama serta meningkatkan penggalangan dan perluasan sumber dana beasiswa. Meningkatkan program pembinaan alumni, pemetaan alumni, penyusunan base alumni dan pemberdayaan alumni. Meningkatkan sistem administrasi, dokumentasi, dan kearsipan kegiatan pembinaan alumni. Meningkatkan pembinaan menghadapi dunia kerja bagi alumni. Memanfaatkan secara optimal prasarana dan sarana kampus yang ada dalam mengembangkan program atau kegiatan kemahasiswaan. Mengupayakan

terwujudnya kerjasama antar-lembaga kemahasiswaan di dalam maupun dengan lembaga kemahasiswaan/instansi lain yang terkait dengan program kesejahteraan mahasiswa; Menata sistem informasi kemahasiswaan secara terencana, terarah, terpadu, dan berkesinambungan; Mengalokasikan dana secara terencana, terarah, dan berkesinambungan sebagai pendukung pelaksanaan program kemahasiswaan; Memanfaatkan secara optimal pembimbing kemahasiswaan; Menerapkan Reward dan Punishment

\section{Program Pengembangan}

$\begin{array}{cccc}\text { Berdasarkan } & \text { program } & \text { kerja } & \text { Rektor } \\ \text { UNDIKMA } & \text { Mataram } & \text { di } & \text { bidang }\end{array}$
kemahasiswaan dan hasil wawancara dengan Ketua Program Studi dan Himpunan Mahasiswa, maka proram pengembangan dibidang kemahasiswaan, meliputi:

a. Tahapan Jangka Pendek (1 s.d. 2 tahun), dengan sasaran:

1. Tertanamnya pengertian tentang hakikat pendidikan tinggi sebagai masyarakat dan institusi ilmiah.

2. Berkembangnya program-program kemahasiswaan yang dapat menampung kebutuhan dan minat mahasiswa.

3. Berkembangnya kesadaran dosen sebagai pendidik untuk mendukung terlaksananya kegiatan kemahasiswaan.

4. Tersedianya dana dan sarana pengembangan kemahasiswaan.

5. Berkembangnya sistem informasi kemahasiswaan di UNDIKMA
Mataram.

6. Meningkatnya kegiatan bidang penalaran, minat dan kegemaran, kesejahteraan mahasiswa (kuantitas dan kualitas) serta kegiatan-kegiatan yang bernuansa Islami

7. Difungsikannya secara opimal Ikatan Alumni UNDIKMA Mataram dengan mengadakan penelusuran dan penelitian tentang profil alumni serta optimalisasi pemanfaatan website UNDIKMA Mataram untuk membuka jaringan dengan alumni dan pemberdayaan alumni UNDIKMA Mataram untuk peningkatan kualitas lulusan (pelatihan kewirausahaan dan lain-lain)

8. Pe ningkat a n hubungan kerjasama dengan dunia usaha.

b. Tahapan Jangka Menengah (kurang lebih 5 tahun), dengan sasaran:

1. Terciptanya iklim dan lingkungan akademik (academic milieu) di UNDIKMA Mataram sebagai prasyarat berkembangnya proses akademik yang lancar.

2. Mantapnya organisasi kemahasiswaan di UNDIKMA Mataram.

3. Berkembangnya program kemahasiswaan yang bermutu dengan pengelolaannya yang efisien, merata, serta lebih relevan dengan perkembangan iptek dan harapan masyarakat. Meningkatnya dana dan sarana kemahasiswaan di UNDIKMA Mataram.

4. Terciptanya jaringan informasi kemahasiswaan secara nasional dengan tersedianya data yang akurat, lengkap, dan tepat waktu.

c. Program Jangka Panjang (kurun waktu 25 tahun) dengan sasaran.

1. Terciptanya masyarakat dan lembaga ilmiah yang memiliki tradisi akademik dengan penghayatan akan nilai, norma, dan etika ilmiah yang semakin dijunjung tinggi oleh seluruh warga sivitas akademika. 
2. Berkembangnya sistem pendidikan tinggi yang mantap dengan pengembangan kemahasiswaan yang terprogram dan berkesinambungan yang menjamin tercapainya tujuan UNDIKMA Mataram dan pendidikan nasional.

3. Tersedianya dana, sarana dan prasarana pendidikan yang semakin memadai.

4. Terselenggaranya sistem informasi pendidikan tinggi yang mantap sejalan dengan kemajuan iptek dan perkembangan pendidikan yang tinggi yang relevan dengan pembangunan nasional.

\section{B. Karakter Kepemimpinan yang Dibentuk melalui Kegiatan Himpunan Mahasiswa Program Studi}

Karakter kepemimpinan yang menjadi indikator dalam penelitian ini mengacu pada enam ciri atau sifat yang harus dimiliki oleh seorang pemimpin. Keenam sifat tersebut adalah 1) Cerdas; 2) Disiplin; 3) tanggung jawab; 4) jujur dan benar; 5) berani mengambil resiko; dan 6) inovatif.

Dari hasil wawancara dengan ketua Program Studi dan mahasiswa Himpunan Mahasiswa, ditemukan bahwa karakter cerdas dibentuk dalam himpunan mahasiswa. Cara membentuk karakter cerdas yang dilakukan adalah dengan menguji/ memberikan kesempatan kepada mahasiswa untuk mengerahkan ke- mampuannya dalam membuat program kegiatan sendiri. Mahasiswa menentukan bagaimana rancangan kegiatan akan dibuat seperti apa. Mahasiswa dituntut harus dapat menyusun rencana kegiatan secara mandiri dengan baik hingga kepada masalah teknisnya.

Karakter berikutnya adalah semangat, kuat, dan tangguh. Karakter tersebut dalam hal ini yang dimaksudkan adalah pemimpin memiliki semangat dan keyakinan dalam usahanya sehingga bekerja dengan optimisme yang tinggi, dapat diambil kesimpulan bahwa karakter ini dibentuk melalui himpunan mahasiswa. Karakter ini penting karena dengan semangat, kuat dan tangguh, pemimpin mampu mempengaruhi pengurus lain dan anggota untuk turut semangat dalam berkegiatan sampai tuntas. Dengan semangat, kuat, dan tangguh pemimpin berusaha bekerja dengan optimis yang tinggi dalam menjalankan roda kepemimpinan yang digerakkan.

Karakter ketiga yang diteliti adalah tanggung jawab. Tanggung jawab dalam hal ini adalah pemimpin bertanggung jawab atas segala tugas yang diembannya. Dari hasil wa- wancara dengan ketua Program Studi dan mahasiswa diketahui bahwa ada upaya yang dilakukan oleh ketua Program Studi untuk dapat menumbuhkan karakter tanggung jawab pada diri mahasiswa. Upaya untuk menumbuhkan karakter tersebut dilakukan dengan memberikan kepercayaan untuk menjalankan program-program secara bertanggung jawab. Selain itu, mahasiswa juga harus bisa berubah ke arah yang positif. Dari yang sebelumnya tidak disiplin menjadi disiplin, dan memiliki tanggung jawab yang besar. Karakter keempat yang diteliti adalah jujur dan benar. Jujur dan benar dalam hal ini diukur dari komponen berupa pemimpin tidak berbohong, berkata apa adanya dalam kebenaran, dan tidak curang. Hasil wawancara dengan beberapa narasumber adalah bahwa pengurus, dalam beberapa kesem patan, harus melaporkan hasil pekerjaannya sebagai bahan evaluasi terhadap program apa saja yang sudah tercapai. Dengan demikian pengurus akan selalu dituntut untuk jujur dalam melaksanakan tugasnya.

Selain itu terlihat juga bahwa ketua Program Studi memiliki upaya untuk menumbuhkan sikap jujur oleh masing-masing pengurus himpunan dalam menjalankan program kerjanya. Karena karakter jujur itu harus dimiliki dan dilakukan oleh pemimpin juga anggotanya. Dan kejujuran itu merupakan salah satu kunci seorang pemimpin adakn dipercaya oleh bawahnnya Karakter kelima yang diteliti adalah berani mengambil resiko. Karakter tersebut dalam penelitian ini yang dimaksud adalah pemimpin memiliki rasa percaya diri yang besar dalam menghadapi bahaya, kesulitan, dan tidak takut mengambil resiko. Dari hasil wawancara dengan ketua Program Studi dan mahasiswa, dapat disimpulkan bahwa ketua Program Studi melalui kegiatan himpunan melakukan upaya penanaman karakter berani mengambil resiko dalam 
menjalankan program himpunan mahasiswa. Hal ini dibuktikan dengan adanya usaha ketua program Studi dengan memberikan kepercayaan kepada mahasiswa untuk menjalankan program himpunan yang telah direncanakan.

Karakter terakhir yang diteliti adalah inovatif. Inovatif dalam hal ini adalah pemimpin melakukan pembaharuan, menciptakan sesuatu yang baru, dan kreasi yang baru. Hasil wawancara dengan ketua Program Studi dan mahasiswa disimpulkan bahwa ketua program studi melalui kegiatan himpunan melakukan upaya tidak langsung penanaman karakter inovatif dalam menjalankan program himpunan mahasiswa. Hal ini dibuktikan dengan adanya usaha dari mahasiswa dalam menentukan bagaimana rancangan sebuah kegiatan. Selain itu, mahasiswa dalam berorganisasi diberikan kebebasan dalam mengapresiasikan inisiatif mereka untuk mengadakan kegiatan-kegiatan yang berbeda dari tahun sebelumnya.

Temuan-temuan yang didapatkan dari wawancara terhadap karakter kepemimpinan yang dibentuk melalui kegiatan himpunan mahasiswa sebagaimana telah dijabarkan di atas menunjukkan bahwa dari enam karakter yang dijadikan acuan/indikator karakter kepemimpinan, semuanya dibentuk dalam kegiatan mahasiswa. Sebagaimana dapat dilihat dalam pembahasan di atas, ket erangan tentang pembentukan karakter te sebut diperoleh baik dari pihak ketua Program Studi, pengurus, mau pun anggota himpunan. Namun, dalam pembahasan beberapa karakter, tidak disebutkan secara eksplisit oleh sebagian narasumber, misalnya tentang karakter berani mengambil resiko dan inovatif yang tidak disebutkan oleh ketua Program studi.

Meskipun demikian, hal yang tidak disebutkan tersebut kemudian ditemukan dalam keterangan narasumber lain yaitu pengurus dan anggota tersebut dapat dikatakan bahwa karakter yang dibangun menghasilkan bentuk karakter kepemimpinan mengarah kepada "Authentic Leadership". Namun demikian, jika diuraikan dengan karakter "Authentic Leadership", masih ada beberapa kekurangan karakter lainnya yang dibentuk. Pada dasarnya kepemimpinan autentik (authentic leadership) menekankan pada proses membangun legitimasi pemimpin melalui hubungan yang jujur dengan bawahan, menghargai masukan, serta dibangun di atas landasan etika. Sama halnya dengan fenomena yang terjadi pada kegiatan DPM, BEM HMJ, UKM.Di mana dalam setiap kegiatan membangun legitimasi pemimpin dengan menjalin hubungan antara atasan dan bawahan secara jujur dan mem iliki etika yang cukup baik.

Seperti halnya yang dikatakan oleh Walumbwa et al. (2008) yang mendefinisikan bahwa kepemimpinan autentik sebagai pola perilaku pemimpin yang mengacu pada kapasitas psikologis yang positif dan iklim etika positif, untuk kesadaran diri, internalisasi nilai moral, pengelolaan informasi yang seimbang, serta transparansi hubungan antara atasan dan bawahan guna membina pengembangan diri yang positif. Hal inilah yang terjadi pada organisasi Himpunan Mahasiswa Departemen pada DPM, BEM HMJ, UKM. Selain itu, menurut Wirawan (2013, hlm. 247 kepemimpinan autentik artinya dapat di- percaya, asli, tulen atau sah. Sesuatu dapat dikatakan autentik jika sesuai dengan fakta apa yang dilihat, didengar dan dirasa sehingga dapat dipercaya. Sesuatu yang autentik adalah bonafide (jujur, dapat dipercaya), genuine (sejati, asli), real (riil, nyata, sejati), true (benar, betul), undoubted (tidak dira- gukan), unquestionable (tidak dapat disangkal). Dari hasil penelitian ini, karakter yang terbentuk pada DPM, BEM HMJ, UKM secara tidak langsung muncul secara sendirinya melalui tugas dan amanah yang mereka emban. Meskipun, ada penekanan bahwa mereka terbentuk karakternya melalui kegiatankegiatan yang dilakukan. Namun, pada dasarnya manusia memang memiliki karakter kepemimpinan, terlebih jika diasah dan diimplementasikan dalam organiasai akan memunculkan karakter kepemimpinan menjadi lebih menonjol.

Gaya kepemimpinan pada dasarnya tidak membedakan pemimpin yang autentik dan tidak. Pemimpin yang autentik bertindak sesuai keyakinan tertentu, untuk membangun kredibilitas dan mendapatkan kepercayaan dari bawahan dengan memfasilitasi perbedaan cara 
pandang serta membangun jaringan kerjasama dengan bawahan dan dengan cara itu bawahan melihat atasannya sebagai pemimpin yang otentik

\section{KESIMPULAN}

Simpulan yang dapat diberikan berdasarkan temuan dan pembahasan hasil penelitian di atas adalah sebagai berikut:

1. Ketua Program Studi melakukan komunikasi yang baik dalam setiap kegiatan. Komunikasi yang dilakukan antara ketua Program Studi maupun dengan Himpunan Mahasiswa disesuaikan dengan kebutuhan apa yang akan dikomunikasikan. Jika berkaitan dengan kemahasiswaan, pengurus lebih berkomunikasi dengan Ketua Program Studi kemudian dilanjutkan ke tingkat Fakultas.

2. Visi misi yang telah disusun dan telah disepakati bersama antara Himpunan mahasiswa dan ketua program studi kemudian diajukan untuk pengesahan atau penetapan oleh fakultas.

3. Ketua Program Studi tetap ikut berpartisipasi dan mengetahui bagaimana perkembangan dari perencanaan kegiatan sampai pada pelaksanaan kegiatan melalui Ketua Himpunan Mahasiswa.

4. Pendelegasian dari ketua program studi kepada dosen pembimbing maupun kepada mahasiswa Himpunan, mereka melakukan pola delegasi yang sesuai dengan kebutuhan dan bertujuan untuk tercapainya tujuan organisasi.

5. ketua Program Studi masing-masing memiliki peran di dalamnya, porsi dari peran keduanya disesuaikan dengan tingkat kebutuhan pada saat dibutuhkan dan disesuaikan dengan situasi dan kondisi yang ada dan secara keseluruhan berperan sebagai pengarah sebagai ujung tombak pengawasan dan pembinaan di lapangan.

6. Karakter Kepemimpinan yang dibentuk melalui Kegiatan Himpunan Mahasiswa Program Studi antara lain: Cerdas, Disiplin, tanggung jawab, jujur dan benar, berani mengambil resiko, dan inovatif.

\section{DAFTAR PUSTAKA}

Jurnal Ilmu Sosial dan Pendidikan
Amirullah. 2015. Kepemimpinan \& Kerjasama Tim. Jakarta : Mitra Wacana Media.

Engkoswara \& Komariah A. (2012). Administrasi Pendidikan. Bandung: Alfabeta. Hasibuan, Melayu S P. 2011. Manajemen Sumber Daya Manusia. Jakarta : PT. Bumi Aksara.

Kouzes M. James dan Barry Z. Posner. 1997. Kredibilitas. AntonAdiwiyoto. Jakarta : Profesional Books.

Komalasari, K. \& Saripudin, D. (2017). Pendidikan karakter (Konsep dan aplikasi living values education). Bandung: Refika Aditama.

Komariah, A. \& Kurniady, D. A. (2017). Authentic Leadership: Strategy of the Implementation of Madrasah Management of Change. Jurnal Pendidikan Islam Vol. 6, Nomor 2, Desember 2017, hlm. 293 - 810.

Miles, M. B., \& Huberman, A. M. (2007). Analisis data kualitatif: Buku Sumber

Tentang MetodeMetode Baru. Jakarta: Universitas Indonesia Press. Moleong, L. J. (2002). Metodologi penelitian kualitatif. Bandung: Remaja Rosdakarya.

Peraturan Presiden Republik Indonesia Nomor 87 Tahun 2017 tentang Penguatan Pendidikan Karakter.

Peraturan Presiden Republik Indonesia Nomor 232 Tahun 2000 tentang Pendidikan Tinggi.

Sugiyono. (2011). Memahami penelitian kualitatif. Bandung: Alfabeta.

Sugiyono. (2016). Metode penelitian pendidikan (Pendekatan kuantitatif, kualitatif, dan $R \& D)$ ). Bandung: Alfabeta.

Undang-Undang Republik Indonesia Nomor 20 Tahun 2003 tentang Sistem Pendidikan Nasional. 
Wahjosumidjo. (2001). Kepemimpinan kepala sekolah (tinjauan teoritik dan permasalahannya). Jakarta: PT Rajawali Grafindo Persada

Wirawan. (2013). Kepemimpinan (teori, psikologi, perilaku organisasi, aplikasi dan penelitian). Jakarta:

PT Rajawali Grafindo Persada

Kartono, Kartini Dr. 2010. Pemimpin dan Kepemimpinan. Jakarta : PT. Raja Grafindo PersadaGrafindo Perkasa.

Rivai, Veithzal. 2003.epemimpinan dan Perilauk Organisasi. Jakarta : PT. Raja Grafindo Persada. 